American Journal of Economics and Business Administration 2 (2): 169-171, 2010

ISSN 1945-5488

(C) 2010 Science Publications

\title{
Dynamics of Corporates and Stakeholders Perspective of Corporate Social Responsibility: A Case of Sports Goods Industry Meerut
}

\author{
R.K. Tyagi \\ Department of Business Studies, Institute of Informatics and Management Sciences, Meerut, India
}

\begin{abstract}
Problem statement: The Corporate Social Responsibility concerns got global attention in large scale industries but the SME's which are no less prone to create critical problems for the human, social and natural environments inimical to the society as a whole and survival at large, have not attracted the required attention. The case focuses on the dynamics of the corporate and stakeholder perspective on CSR in Sports Goods Industry Meerut. Approach: This study examined the corporate and stakeholder perspective in purview of CSR on a systematic random sample of hundred each with the help of seven interview schedules. Results: Both the parties affirm that sincere commitments to CSR notions need to be exercised in business. But the mutual interaction in cordial and congenial social environment is manifestly neglected. There is neither any institutionalized mechanism of consultation and participation into decision making process, nor any strategy to incorporate stakeholders concerns in the business process of growth. Of course both the sectors avoid conflict creating situations in their own interests. But there is no positive approach to gratify or even identify the problems of stakeholders. The corporate in SGI Meerut verbalize the awareness and necessity of incorporating CSR concerns in business yet nothing serious is being done in this direction. Conclusion: Predominantly the classical view of maximizing profit and economic concerns of business prevail. The present study recommends for an intellectual debate to vitalize CSR concept in SMEs; institutionalized mechanism to develop a healthy interaction both for the comprehension of CSR, addressal and redressal of needs of various component sectors of this category of industries, particularly the stakeholders; attention to communicate human sensibilities pertaining to natural, social and environmental concerns of the mankind of all sectors engaged in industrial enterprises i.e. production, consumption, supply and sale; economic interests should not alone be given priority at the cost of social and environmental concerns.
\end{abstract}

Key words: Corporate social responsibility, globalization, SME's, corporates, stakeholders, sports goods industry, sports goods export promotion council of India, sports goods industry Meerut

\section{INTRODUCTION}

There is a growing realization across the globe that the production processes and the industrial organization of business have an important deportment on the social welfare (India Committee of the Netherlands, 2002). Stakeholder engagement is a key aspect of corporate social responsibility as it enables a shared understanding of the impact of industry operations with its stakeholders (Nirenberg, 2004). For this, it is necessary for the industry to exhibit how it understands the long-term community development as part of its core responsibilities and competencies. The recent revival of interest in improving the lives of the poor working people and encouraging the use of a set of standards or specified code of conduct is a result of the articulation of an evolving global awareness on ethical and social concerns, particularly among partners engaged in cross-border trade (Satyarthi, 2008). According to a study conducted by Bachpan Bachao Andolan (BBA) in association with International Labor Rights Forum, 2008, one can come across hundreds of young children stitching artificial leather pieces stamped 'child labor free' in the slums of Budh Vihar, Kamal Pur (outskirts of Meerut) and Shiwal Khas (the nearby pocket). Meerut with a population of 1,074,229 is one of the largest supplier of sports goods (Tyagi, 2009).

The greater media exposure, environment, education and health related incidents that have caused public anxiety and local community conflict resulting from planning decisions have ensured that effective management of stakeholders has risen up the list of priorities, thus making it important to embrace the 
stakeholder groups and individuals by considering or including them in decision making. This case study profiles Sports Goods Industry Meerut (SGIM) to develop an understanding of Corporate Social Responsibility perspective within the operations of SGI in Meerut based on two counts-one is that being a resident of Meerut the case writer is familiar with their activities. Familiarity can be an advantage in probing the motives of the people engaged in a business venture. Secondly, she has her stake in the industry because she is affected by the activities of the industry as such she is a secondary stakeholder making her entitled to demand the fulfillment of social responsibility by the owners of the industry.

Meerut town is in Northwestern Uttar Pradesh state of India and lays Northeast of Delhi, the capital of India. It lies in between the river Ganga and Yamuna. The local daily newspaper Dainik Jagran in a article 'Jitney Ki Zid' on 01 April 2005 quoted that about three-four sports goods manufacturing units were functional in Meerut even before partition of the country in 1947; these units were manufacturing products like footballs, net and balls. The industry has export into countries like Australia, Europe, Germany, Italy, France, Kenya, New Zealand, Middle East, Gulf countries, South Africa, United States of America, United Kingdom and West Indies.

\section{MATERIALS AND METHODS}

The researcher has taken an adductive research approach and mixed methods (quantitative and qualitative analyses). The primary data pertaining to achieve the objectives were collected through seven structured interview schedules developed after initial research. A list of sports goods manufacturers in Meerut was procured from the Federation of sports goods manufacturers. The total number of manufacturers as per the list was 356.With the help of simple random sampling technique 50 were selected for pilot study and from the remaining 306 a sample of 100 manufacturers was drawn with the help of simple random sampling technique. These hundred were contacted for obtaining the required information with the help of an interview schedule.

\section{RESULTS}

The corporate perspective: It has been found that the corporate in Meerut based sports goods industry are aware of the concept of corporate social responsibility. They affirm that sincere commitment to such notions need be exercised in business. They avowedly declare and verbalize it but the contradiction in their assertions in the total gamut of notions and the statistics manifest slackness and indifference to incorporate them into practice. They seem to be concentrating on the classical economic aims of serving the self interest, promoting business and maximizing profits. Self interest, promoting business and maximizing profits seems to be their predominant concern. They pay only lip service to CSR objectives. It has also been observed that the corporate in SGI Meerut do not show such sensibilities to the foreign customers also. They treat the local consumers of their goods at par with the foreign ones. Partnership firms show relatively greater sensitivity to CSR orientation compared to the ownership firms. It has also been seen that the firms established before 1987 are more prone to CSR sensibilities in comparison to the firms established after that time which appear to be embedded in religious-o-cultural orientations of the traditional business class in India and now losing ground in the upcoming business entrepreneurs i.e. the tendency towards charity and donations. There are other indices pertaining to stakeholder's expectations which do support this divergence in words and actions. Corporates in SGI Meerut manifest aversion to enactment of laws to regulate their behavior and practices. They beseech for voluntary incorporation of the concept. The corporates want CSR to be voluntary and not regulated by any laws.

The Stakeholders perspective: There are nine interest groups identified by the corporate. These identified stakeholders are customers, suppliers, competitors, governments, partners, communities, owners, investors, labor and/employees. There are common needs of all the groups. They are all affected by the industry business. Some (employees) earn their livelihood from industry; others (investors) earn returns on their invested money. Thus these groups have common and specific interests. They want themselves to be involved in decision making process. They also expect corporate to accommodate their concerns in business. They further expect the corporate to create some institutionalized mechanism of regular interaction to comprehend their difficulties and discussing way out to accommodate their problems. Getting a feedback would benefit the business in general.

\section{DISCUSSION}

The industry: The Sports Goods Industry Meerut is a manufacturer of internationally renowned sports goods with three types of establishments big, small and the unregistered units (Tyagi, 2009). Thus the industry 
wields a significant influence on the contemporary built environment. The factors which contributed to the establishment of the industry in Meerut also includes migration of industrialists to Meerut because of partition. The assets of labor availability, transportation and communication facilities are helping in its growth path inspite of no holds barred competition from other manufacturing centers of the SGI's in India (Jalandhar, Gurgaon, Delhi, Mumbai, Calcutta, Chennai-are the cities in India where sports goods Industry are established). The Sports Goods Manufacturers Directory of 2004 includes that Indian sports goods are being exported to more than 100 countries with Jalandhar as the major centre, Meerut in Uttar Pradesh is the second and Gurgaon in Haryana is the third (India Committee of Netherlands, 2002).

The Industry has been troubled by widespread reports in media within and outside the country: In 1995 the first reports appeared in newspapers about the large scale use of child labor and exploitation of adults in the football industry of Sialkot, Pakistan. Later it was found that same problem exists in India (Husselbee, 2004; Hussain-Khaliq, 2004; Football Production, 2005) similar report was quoted in a daily hindi newspaper, Hindustan in an article 'Haath se baney football banane mein Pakistan ke baad meerut duniya mein sabse agey: Bayan kiya meeruthi bacho ka dard'on 02/11/2008.

\section{CONCLUSION}

Predominantly the classical view of maximizing profit and economic concerns of business prevail. The present study recommends for an intellectual debate to vitalize CSR concept in SMEs; institutionalized mechanism to develop a healthy interaction both for the comprehension of CSR, addressal and redressal of needs of various component sectors of this category of industries, particularly the stakeholders; attention to communicate human sensibilities pertaining to natural, social and environmental concerns of the mankind of all sectors engaged in industrial enterprises i.e. production, consumption, supply and sale; economic interests should not alone be given priority at the cost of social and environmental concerns.

\section{REFERENCES}

Football Production, 2005. News Dossier on football production: A compilation of background information on football production. http://www.varldsbutikerna.org/rwdx/mixed/NEW SFootballProduction[1].pdf

Hussain-Khaliq, S., 2004. Eliminating child labor from the Sialkot soccer ball industry: Two industry-Led approaches. J. Corporate Citizenship, 13: 101-107.

Husselbee, D., 2004. NGOs as development partners to the corporates: Child football stitches in Pakistan. Dev. Pract., 10: 377-389.

India Committee of the Netherlands, 2002. Final report: Labor standards in the sports goods industry in India-with special reference to child labor. http://www.indianet.nl/tatarep.html

Nirenberg, J., 2004. Corporate Social Responsibility: Encyclopedia of Leadership, SAGE Publications. http://www.sage-

ereference.com/leadership/Article_n66.html

Satyarthi, K., 2008. Offside: Child labor in football stitching-A case study in Meerut District. Bachpan Bachao Andolan (BBA). http://www.globalmarch.org/news/061008.php

Tyagi, R., 2009. Dynamics of corporate needs and stakeholder needs A CSR perspective of sports goods industry in 'Enhancing Organizational performance through strategic Initiatives: Handbook of Management Cases. Mac Milan Publishers India Pvt. Ltd., ISBN: 10: 023032823-7, pp: 200-205. 